$\mathrm{T}$ he Ralph Bunche Summer Institute (RBSI) is an annual five-week program designed to introduce undergraduate students from under represented racial/ethnic groups or students interested in broadening participation in political science and pursuing scholarship on issues affecting underrepresented groups to the world of graduate study and to encourage application to $\mathrm{PhD}$ programs. This is the 33rd year of RBSI excellence! The 2019 RBSI program, held at Duke University, ran May 26-June 27 under the direction of Paula D. McClain, APSA president-elect.

\section{ABI BERNARD}

Abi Bernard is a senior studying history and government at Cornell University. Born in Haiti and raised in Michigan, she has developed an interest in comparative politics and is considering pursuing a $\mathrm{PhD}$ in that field. Ms. Bernard works as a research assistant in Cornell's government depart-

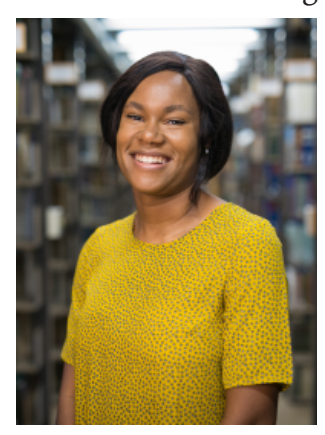

ment and is also a Mellon Mays Undergraduate Fellow, researching gerrymandering in mid-2oth century California. Her past experiences include editing for Cornell's historical journal as well as participating in the Mellon Mays Scholar Program at the Library Company of Philadelphia. She is actively involved in Christian fellowship, Cru, and is passionate about bringing a historicallyrich worldview to the evangelical community for the sake of racial reconciliation, effective social justice, and informed political action.

\section{WILBERT K. DAVIS}

Wilbert ("Wil") K. Davis is a rising senior at Hofstra University's Honors College. Wil is currently double majoring in journalism and political science. In the fall of 2017 , Mr. Davis was initiated into the Alpha Phi Alpha Fraternity, Inc. through the Xi Psi Chapter where he has served as the chapter president since the spring of 2018. In February 2019, he was awarded the Young Drum Major Award by Alpha Phi Alpha Fraternity, Inc, Eta Theta Lambda Chapter for his community service and academic achievement.
Wil was a summer intern (2015 - 2017) at the Selective Corporate Internship Program ("SCIP") located in New York City and was selected as team leader his last two summers. During the summer of 2018, Wil started as a team member at NBC Universal working as an

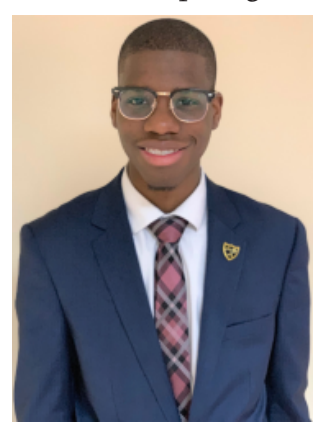
intern for MSNBC host Alex Witt, which was extended through the spring of 2019. After graduation, Wil plans on pursuing his law degree and his doctoral degree in political science. He also aspires to be a political analyst at a major station and eventually run for political office.

\section{JORDAN FARRIS}

Jordan Farris is a third-year honor student majoring in political science at the University of Arkansas. He is a Walmart Endowed Scholar as well as a Camden E. Green Scholar at the university. Mr. Farris has served as an academic coach for eight firstgeneration students, summer mentor and residential assistant for underrepresented

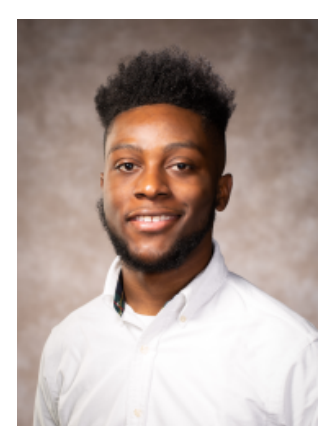
students, and is a founding father of Theta Chi Fraternity. He now serves as a Student Ambassador, and as an Ambassador for the Accelerate Student Achievement Program. In December of 2016, he created an organization geared toward increasing the number of minority students attending an accredited four-year institution. Jordan's work with this organization earned him acceptance to attend Harvard's Kennedy School esteemed Public Policy Leadership Conference in February 2018. After graduating from the University of Arkansas, Jordan plans to seek a $\mathrm{PhD}$ in political science to help strengthen his advocacy for marginalized communities. Jordan is committed to highlighting the pervasive social, economic, and political injustices in our country and believes the most effective way to initiate and galvanize change is through public policy.

\section{SILVIA FERRER}

Silvia Ferrer is a first-generation honors student at the University of California, Riverside, double majoring in political science and English. She is passionate about writing, immigrant rights, and community involvement. Ms. Ferrer has interned at the Superior Court of San Bernardino, the UCR Office of Campus Counsel, and now interns at the Office of Representative Pete Aguilar (D-CA). Her background has shaped her research interests in racial equity, immigra-

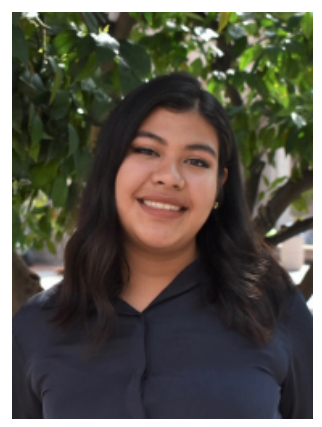
tion policies, and politics within the digital age. Inspired by her own experiences, Silvia is currently conducting her undergraduate honors thesis with Dr. Loren Collingwood on the university experience of undocumented students. She plans to pursue her interest in public service through the AmeriCorps program, then aspires to continue her education by entering a dual JD/political science $\mathrm{PhD}$ program that will join her interest in the law and academia.

\section{ERIKA GONZALEZ}

Erika Gonzalez is a first-generation, honors college senior at the University of Texas Rio Grande Valley (UTRGV), majoring in political science, and minoring in communication studies. She will graduate in December 2019. Ms. Gonzalez volunteers and translates at the Humanitarian Respite Center, the local immigrant shelter. Along with her participation in the Political Science Association (PSA) of UTRGV, she has

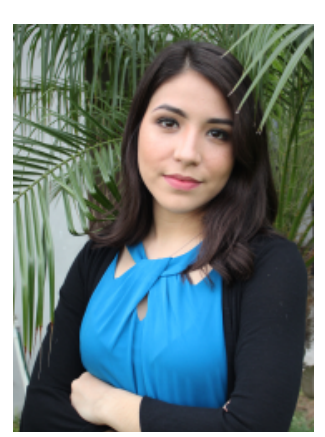
also held two research internships on-campus d e veloping a theory and research paper. The research focused on the effects of deindustrialization on social capital, 
which she presented at Southern Political Science Association, and is due to be presented at Midwestern Political Science Association. She plans on submitting this paper, in collaboration with her professors, for publication. She is also an Engaged Scholar Award (ESA) Recipient which is awarded to undergraduate students for research purposes. Erika plans on continuing her academic journey to earn a $\mathrm{PhD}$ in Political Science, and study the effects of immigration on social cohesion.

\section{GAVIOTA DEL MAR HERNÁNDEZ QUIÑONES}

Gaviota Del Mar Hernández Quiñones is a junior at Washington College in Chestertown, Maryland, where she belongs to the Cater Society, a research fellowship for high-achieving students. Originally from Puerto Rico, Gaviota migrated to the United States to study political science. There, she founded the university's first Latin American Students' Association and became engaged in

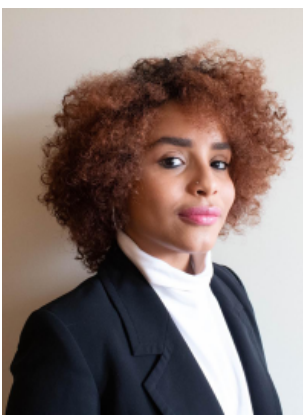
campus life by participating in the Black History Month and Latinx History Month committees. As a teacher assistant for the Modern L a n g u a g e $\mathrm{s}$ Department, she teaches 10o-level and 200-level Spanish undergraduate courses. Hernández Quiñones is also a Community Outreach Coordinator and interviewer for the National Home Front Project, a World War II oral history program. Moreover, she emphasizes the importance of intersectionality as framework for the study of individual and collective political behavior. Upon graduation, Gaviota intends to enroll in an interdisciplinary PhD program in political science to pursue research on US-Latin American relations, democracy, and the establishment of neo-liberalism across the American continent.

\section{JAKINI INGRAM}

Jakini Ingram is a student at The Ohio State University, studying political science and African American Studies. She serves as the vice president of the National Pan-Hellenic Council, Secretary of Alpha Kappa Alpha Sorority Incorporated, a Buckeye Leadership Fellow, the
African American Homecoming Queen, and a First Year Experience Peer Mentor. As a Dean's List Scholar and Morrill Distinction Scholar, Ms. Ingram is e x t r e m e ly passionate about dismantling the educational and legal disparities that plague her community. She is particularly interested in studying the intersection of

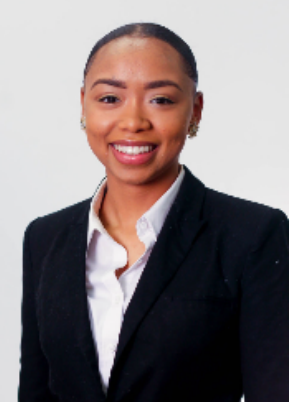
law, race, and politics by researching minority experiences with the American political system. Following her undergraduate studies, Jakini would like to pursue a $\mathrm{PhD}$ in American politics. She hopes to go into public policy and advocacy work on behalf of black men and women who have been dealt with unjustly in legal spaces. She is also considering running for public office. By integrating her experience and knowledge acquired through the Ralph Bunche Summer Institute and PhD degree, she hopes to bring about social change by fostering critical dialogue.

\section{WILLOW LOPEZ}

Willow Lopez is a senior, to graduate in December of 2019, with a major in political science from the University of Dayton. Ms. Lopez consistently excels as a top member of her class. She was selected to participate in the Dayton2DC program which provides her the opportunity to connect with University of Dayton alumni in the federal government. Willow is also a standing member of the academic senate representing social sciences through the Student Government Association at her university. As a passionate advocate for gender equality and increased awareness of sexual violence in the United States. Willow is currently

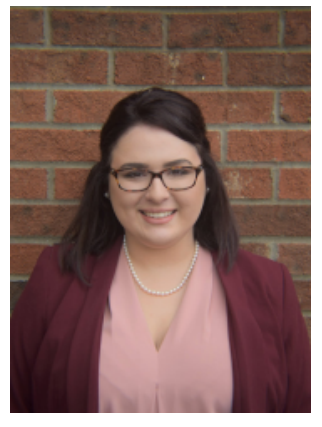
researching the relationship between local government leadership and volume of reported sexual violence incidents within communities along the US-Mexico border. Her post-graduate plans include conducting further research into gender and racial equality and how it impacts the interactions between federal and foreign governments of Latin American countries.

\section{MARIA MARTINEZ}

Maria Martinez is a rising junior at the University of Louisville majoring in political science and Latin American and Latino Studies with a minor in social change. On campus, Maria is involved at the Cultural Center, playing a part in the communications of the Hispanic Latino Initiative. Ms. Martinez just completed her fall internship at Adelante Hispanic Achievers, an organization that assists Latinx youth. Outside of school, Maria volunteers at various nonprofit organizations which focus on immigrant and refugee populations, and their transition to their new environment. This passion for refugee and migrant families

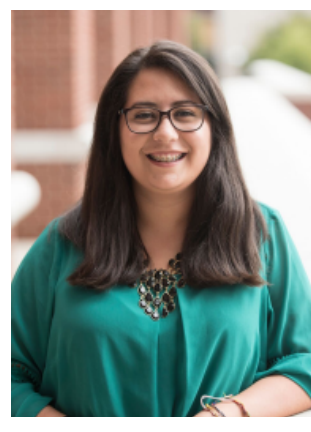
has led Maria to study the systemic gaps which are set for these minority groups. Maria hopes to work in diplomacy through the State Department of the United Nations and use her previous research to inform her work.

\section{BETZAIRA MAYORGA}

Betzaira Mayorga is an honors student at Florida Gulf Coast University. She is majoring in political science, with a minor in economics. Betzaira became motivated to major in political science through her challenges and experience as a college executive officer and a statewide legislative officer, setting the agenda and educating student government members on the legislative process. By advocating for students in the Florida Capital, Ms. Mayorga sparked an interest in advocating for other marginalized communities in the state of Florida with the Florida Student Power Network and Florida I m m igra $\mathrm{n} \mathrm{t}$ Youth Network.

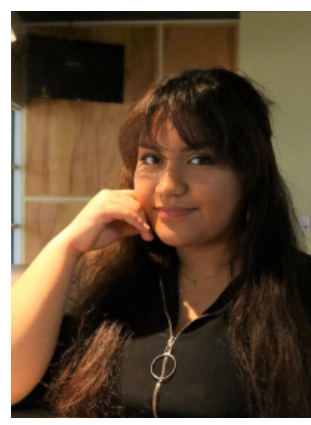
As a DACA recipient and a Latinx woman, Betzaira has played a variety of roles as a spokesperson, panelist, writer, and an organizer on campus and in her community. 
She uses scholarly perspectives to shine light on the complexity of political and social-economic issues being discussed in recent times. She is excited to start a campus podcast this semester focused on the intersection of pop culture, history and politics pinpointing the effects on the regions surrounding the university. She is planning to continue her education by attending graduate school to further expand her ability to research how economic policy affects the structure of economies and communities.

\section{JOSH NNAJI}

Josh Nnaji is a junior at Wake Forest University majoring in politics and international affairs with a minor in sociology. He has a passion for identity politics and speaking up for those who cannot speak for themselves. Mr. Nnaji has served as student senator in Wake Forest's student government during his sophomore and junior years. In the summer of 2018, Josh worked as an intern in the US House of Representatives. He has also conducted and presented research on race and government at the

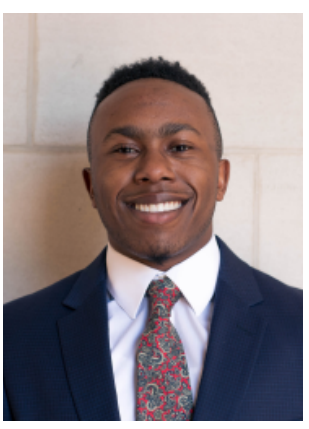
Wake Forest Politics of Race, Immigration, and Ethnicity Consortium and is a member of the Wake Forest chapter of the Pi Sigma Alpha. Josh is interested in studying race and public policy in America, and its potential intersections with African political economy. He plans to pursue a $\mathrm{PhD}$ in public policy after graduation.

\section{JAVIER SALAZAR JR.}

Javier Salazar Jr. is a first-generation college student. He is a Junior at Indiana University, studying law, public policy, and political science. Mr. Salazar has participated in several case competitions for organiza-

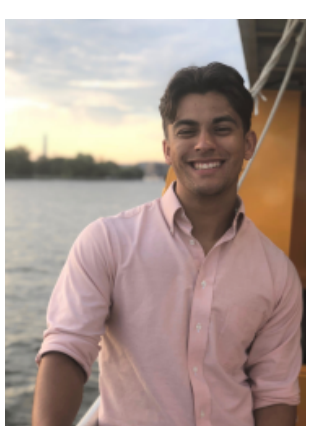
tions including Home Chef and Philanthropy for America, in which he placed third. He is a member of the Indiana Political Analysis Workshop (IPAW), which places undergraduates in graduate-level courses, where they conduct their own research projects. His project focuses on the delta of income for minorities living in blue states, compared to red states, over the past three presidential terms. Javier wishes to continue his education by attending graduate school to pursue a joint degree in political science and statistics. From there, he wants to spread his knowledge by teaching undergraduates.

\section{IGNANGELI SALINAS-MUNIZ}

Ignangeli Salinas-Muniz is a political science major and a rising senior at the University of Puerto Rico-Mayaguez Campus. She has participated at the Organization of American States (OAS), spoken at local radio stations, and has worked

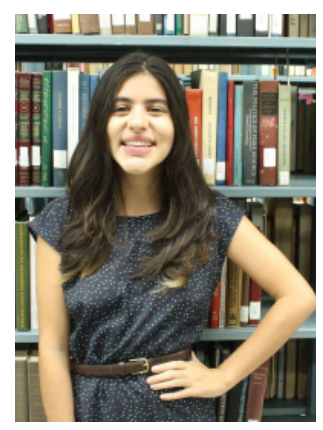
with activist organizations like Diversxs. As part of Summer Research Opportunities Program ( S R O P) at Purdue University and under the mentorship of Dr. Nadia Brown, she used a mixed methods approach to determine the influence of the Trump's administration's policy agenda on minority women candidate's decision to run for office. Ms. Salinas-Muniz has also worked as a research assistant on the "Media Coverage and Political Polarization in the United States" project by NYU professor Dr. Querubin. She has worked as a participative action research mentor at El Instituto Universitario para el Desarollo de Comunidades and briefly at El Instituto Nacional de Energia y Sustenibilidad Islena. She has also been an intern at a congressional office in Washington, DC as part of the Cordova and Fernos Congressional Internship Program. Salinas-Muniz is a recipient of The Hurricane Maria Assistance Program Scholarship at NYU. She has a passion for the study of political participation and hybrid regimes. Her research interests include: women and ethnic politics, comparative politics, political economy and public policy.

\section{PYAR SETH}

Pyar Seth is a student at Trinity University with majors in political science and African American Studies and minors in education and history. Seth's research interests include class meaning, citizenship, democracy, liberalism, nationalism, postmod-

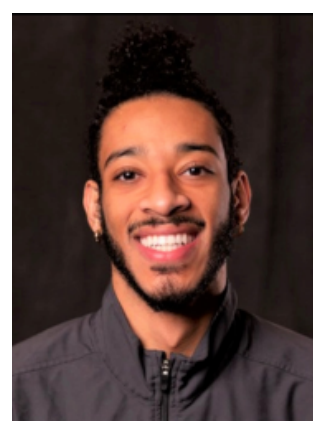
ernism, political philosophy, and race. His research agenda more specifically relies on the logic of scholars such as W.E.B DuBois, Malcolm X, and Michel Foucault. Pyar hopes to consider the extent to which these scholars' various notions of power and freedom come to complicate our understanding of the state and everyday life. He is also currently working on a paper with Dr. Sarah Erickson on democratic enthusiasm and racial attitudes. After graduation, Pyar plans to pursue a doctoral degree in political science with a concentration in political theory.

\section{JORDAN SPENCER}

Jordan Spencer is a junior at the University of Delaware majoring in history education with a minor in political science. As a fivetime Dean's List recipient, a resident assis-

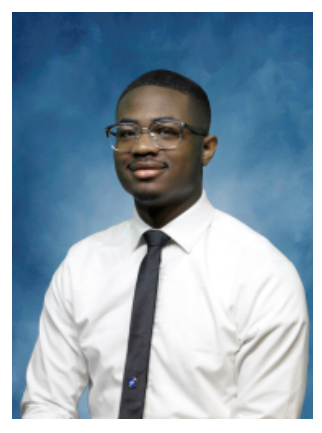
tant, a Ronald E. McNair Scholar, and a proud member of the fraternity Alpha Phi Omega, Jordan proves he is a well-rounded student. In his fraternity, Mr. Spencer gives back to his college community by completing twenty hours of community service every semester. As a Ronald E. McNair Scholar, Jordan has conducted research with Dr. Andrew Brown of the University of Delaware on race and sexuality in masculine production sports like basketball and football, highlighting the lack of black LGBTQ+ athletes in these sports. Jordan's research interest includes American politics, urban politics, and racial and ethnic politics. After graduation, Jordan plans to pursue a doctoral degree in political science and become a well-respected professor, and political analyst. 